\title{
'New Perspectives in Forestry': a Basis for a Future Forest Management Policy in Great Britain?
}

\author{
J.L. INNES
}

Swiss Federal Institute for Forest, Snow and Landscape Research Zurcherstrasse 111, CH-8903 Birmensdorf, Switzerland

\section{SUMMARY}

Common forestry practices are being increasingly questioned in many countries. In Great Britain, controversy has surrounded a number of issues, including upland afforestation, single-species plantations and water acidifcation. With increasing international attention being given to the issues of sustainability and biodiversity, there will be pressure for developed countries to evolve policies that will satisfy their own internal responsibilities before they attempt to impose 'sound management principles' elsewhere. Many of the principles currently being discussed have been brought together under the term 'new perspectives in forestry', although some of these were actually developed and practised in Europe during the last century. Multipurpose forestry has been advocated as a means of achieving many goals, but a genuine application of this approach will require further changes to existing priorities and practices. Under 'new forestry' principles, forests are seen as ecosystems and management practices seek to ensure that the integrity of the ecosystems is maintained. In addition, a greater involvement of all interested parties is sought, both in the forest planning process and in subsequent management.

\section{INTRODUCTION}

This paper is concerned with an examination of some of the changes that are occurring in some sectors of forestry. Particular emphasis has been placed on recent developments in North America, where general concern about the validity of current forest management techniques is increasing (e.g. Salwasser, 1990; Clark and Stankey, 1991). The situation in Great Britain is somewhat different from most other developed countries in that the pressure from environmentalists has largely been focused on preventing further afforestation of 'sensitive' sites rather than improving the management of existing forests. However, with planting levels (12 000 ha in 1991) falling well short of the 33000 ha annual planting targets, the emphasis may well change to the management of the existing forest resource and it is

Forestry, Vol. 66, No. 4, 1993 
interesting to note in this context proposals for the preservation of 'oldgrowth' stands of conifers in the uplands (Peterken et al., 1992).

This paper attempts to draw attention to some of the important issues that are being discussed in certain circles (especially in North America) but which, so far, appear to have been little addressed in Great Britain, despite the recent publication of wildlife management guidelines by the Forestry Commission. In particular, the ecosystem approach to forest management is very relevant to issues of general concern, particularly the use of sustainable forest management practices, the maintenance of biodiversity and ethical standards in forestry. These themes are explored below.

Some of the discussion about new management policies has been extremely vague and appears to have been undertaken outside the context of practical forest management. It is hoped that by opening up the discussion of the issues within the British context, the greater interaction between ecological scientists, environmentalists and forest managers will enable some of the issues to be resolved. While significant progress has already been made, it is clear that many of the issues have not been fully resolved, and further debate seems warranted. Many of the issues discussed in this paper have already been or are in the process of being adopted in Switzerland. During the last 10 years, there has been a major increase in the emphasis placed on ecological and landscape aspects of forest research, as illustrated by the recent establishment of a Chair of Nature and Landscape Conservation in the Department of Forest and Wood Research at the Federal Institute of Technology in Zurich. The relative importance of ecologically-oriented forestry research is expected to continue to increase in the future.

\section{THE DEVELOPMENT OF CONCERN}

Over the last few years, some foresters may have noticed that their activities have occasionally been viewed as being environmentally unfriendly. Such views are not restricted to Great Britain; activities seen by some as detrimental to the environment range from the felling of tropical rain forests through the logging of old-growth forests in northwest America and southern Chile to the continued afforestation of sensitive parts of the British uplands. The prime motivations behind these different forms of resource use are complex and cannot be discussed here. However, economics plays an important part and short-term financial motives have encouraged the use in some parts of the world of forest practices known to be not only ecologically detrimental but also poor silviculture (e.g. Nyland, 1992).

Within Great Britain, pressure for a change in the management of forests has come primarily from groups concerned with conservation, public access and other aspects of forests unrelated to timber production. This contrasts markedly with the United States and Canada where, increasingly, the 
pressure for change is coming from within the forest industry itself. Forestry Canada now has a 'Science and Sustainable Development Directorate' whereas the US Forest Service has the 'New Perspectives for Management of the National Forest System' programme. It is rather unlikely that the following statements would be made by a senior forestry administration official in Great Britain: 'Silviculturalists must learn to think of their work as an art form in which the landscape is a canvas. The public has the right to reject silvicultural treatments on the basis of appearance, and rejection does not have to be justified on a logical basis' (Beasley, 1992). Yet Lamar Beasley was the Director of the Southeastern Forest Experiment Station of the U.S. Forest Service at the time the statements were made and he is currently the Deputy Chief, Administration, of the Forest Service. The Society of American Foresters has issued position statements on several of these critical issues.

A whole series of major environmental issues have emerged in Great Britain in connection with forestry over the past 30 years. These include the replacement of semi-natural broadleaved woodland with conifers, the afforestation of areas of conservation and archaeological value and the role of forests in the increased acidification of streams. Generally, it has often been special interest groups that have identified a problem and the forest industry has then had to defend its practice. An exception is the interest that has been expressed in group-felling and single tree-felling as an alternative to clear-cutting. The divergence of opinion between special interest groups and foresters has not helped the development of a co-operative attitude to the solution of forestry problems. Even when the issue of 'forest decline' arose, the forest industry was generally at odds with the environmental movement, despite a clear common interest in the health of forests. These problems, together with many future ones, might be resolved through a change in attitudes towards forest management.

Brooks and Grant (1992a) have argued that the pressure to reconsider forest management practices actually coincides with a much greater awareness of the environment by the public. Beasley (1992) takes this a step further, arguing that people see the qualities of natural and man-made environments as a reflection of the quality of their own lives, providing a suggestion as to why the environment creates such strong feelings in many people. In Great Britain, criticism of forestry practices has not always been well-founded. However, some recent studies have contained a more balanced view, the studies by Avery and Leslie (1990) and Harris and Harris (1991) being good examples. Despite the latter, the debate between forestry and ecology remains much more polarized than it needs to be. Beasley (1992) sees this as reflecting the discrepancies between what some people expect a forest to look like and the reality of productive plantation forests. 


\section{THE CURRENT POSITION}

Forest ecosystems have not been given a particularly prominent place in many forestry handbooks in Great Britain. For example, in an otherwise excellent textbook on forestry, Hart (1991) devotes 0.2 per cent of his text to the subject, although there is a substantial section on the non-wood benefits of forestry. The Forestry Commission's Forestry Practice (Hibberd, 1991) places more emphasis on topics such as wildlife management but over a third of the chapter on wildlife concerns the prevention of damage by wildlife and wildlife 'control'. Nevertheless, there has been a clear shift in emphasis in publications dealing with management practices (particularly those from the Forestry Commission) towards an approach to forestry that is more sympathetic to multi-purpose needs.

The outcomes of two recent conferences provide an indication of recent trends. Some of the problems associated with long-term forest management were identified in the Paris Declaration produced at the 10th World Forestry Congress. Relevant excerpts of this declaration include the following assertions:

- 'that the real challenge is to reconcile the economic use of natural resources with protection of the environment through integrated and sustainable development';

- 'that forest management plans can be used as comprehensive tools for managing the economic, ecological, social and cultural functions of the resource, thus enlarging the concept of sustained yield';

- 'that the preservation of specific forest areas in order to protect biodiversity constitutes a particular objective of forest management policy';

and recommendation:

- 'that land-management planning be based on the land's potential and on long-term priorities in order to determine sites that are best suited to be forested; and that the needs of all people concerned, particularly those who depend on forests for their livelihood, should be carefully taken into consideration at the planning stage'.

Just how the first two assertions are likely to operate is unclear. Several themes run through the declaration, the most important of which seem to be the requirement to integrate the needs of society in forest planning, the need for sustainable forestry practices and the need to maintain biodiversity. These themes are very different to past priorities in forest management and, consequently, need to be based on sound scientific principles. However, at the same time, it is important to recognize that many decisions being taken today are not based on the available scientific evidence but instead are based on political views (Gregg, 1992).

At the United Nations Conference on Environment and Development 
(UNCED) held in June 1992, a forest principles document was eventually signed which aimed at providing a set of international guide-lines for the sustainable management of forests. The principles set out to provide a 'nonlegally binding authoritative statement of principles for a global consensus on the management, conservation and sustainable development of all types of forests'. Three main aims were presented in the document:

1. that concerns about forests should be focused globally;

2. that there should be a 'greening of the world';

3. that the involvement of local and indigenous people was a prerequisite of any sustainable management.

None of these could be considered to be particularly controversial or authoritative, and their vagueness enabled international agreement to be obtained, particularly as the final document only committed signatories to keeping the principles 'under assessment for their adequacy with regard to further international co-operation on forest issues' (Parson et al., 1992). More contentious issues in the document covered areas such as national sovereignty, internationally accepted forest management guide-lines, technology transfer, trade in forest products, rights of indigenous peoples, valuation of forest products, market access, financing and the need for an international convention on forests. This last issue was particularly resisted by countries such India, Malaysia and Indonesia and agreement over the document was only reached when the commitment to negotiate a forestry convention was removed from the document. The document failed to present any plan for international co-operation to the solution of global forest problems, and the failure of the UNCED conference to reach a more authoritative set of principles reflects the wide gaps between how forest resources are viewed in different countries. However, this should not prevent individual countries from developing their own sets of principles.

\section{'NEW PERSPECTIVES IN FORESTRY'}

While there has been criticism of existing management techniques, there have also been some constructive attempts to devise revised management guidelines, particularly in relation to the practice of clear-felling (e.g. Maser, 1988). In the United States, the general concern about existing practices resulted in the development of a series of proposals that can be loosely grouped under the term 'new perspectives in forestry' (Franklin, 1989, 1990; Gillis, 1990), although the methods being proposed are anything but new (Brooks and Grant, 1992c). The approach has seen greatest interest in North America, but similar changes in emphasis are beginning to appear in Great Britain and elsewhere. Although it is tempting to view the proposals as being part of the movement labelled 'eco-extremism', the 'new perspectives' have been taken seriously in the United States, with the Chief of the Forest Service, Dale 
Robertson, defining them as 'A multiple-use philosophy built around ecological principles, sustainability, and a strong land stewardship ethic, with a better recognition of spiritual values and the natural beauty of forests' (Robertson (unpublished), quoted in Graham (1992)).

An important principle of the 'new perspectives' is the emphasis that is placed on an ecosystem approach to forest management. This is not new, and a similar approach has, for example, been practised in some European forests (particularly in Switzerland) since the nineteenth century. The forestry texts of Gayer (1889) and Landolt (1895) argued very much along these lines and, since then, there has been considerable interest in the use of management techniques that are broadly sympathetic to what could be considered as ecological principles (e.g. Hornsmann, 1958; Mantel 1961). The concept of sustained yield (Nachhaltigkeit) has received considerable attention in central Europe and elsewhere (e.g. Heyer, 1841; Waldbauer, 1947; Mantel, 1961; Zürchner, 1965). This principle was particularly advocated by Gayer (1889), but it has been criticized for its failure to take into account the multiple functions of forests. However, this seems to arise from the wide range on interpretations of the principle that have arisen. The principle has formed the basis for forest management in many parts of Switzerland and is today widely practised in one form or another in many parts of the world (Gane, 1992). It is interesting to note that while the management practice was initially developed in relation to sustained production, it has a large number of spin-offs which satisfy many of the demands currently being placed on modern forest management (Arbeitsgruppe Waldbau des Schweizerischen Forstvereins, 1990). The concept is not restricted to Central Europe, with several forests in, for example, North America, having been managed under the same principles during this century (e.g. Pecore, 1992).

Under the principles of the 'new perspectives', one of the most important changes is the need for trees to be seen as part of forest ecosystems, not simply as crops. By doing so, a number of major concerns should be immediately addressed, including biodiversity, sustainability and multiple use. Claims will no doubt be made that forestry already adopts such an ecosystem approach although this assertion is not always supported by the available evidence (Brooks and Grant, 1992c). Similarly, although multipurpose forestry is a supposed cornerstone of British forest management, there is often little evidence of it other than the special allowance of the public sector discount rate being reduced to 3 per cent in comparison to the 6 per cent asked of other public sector investments.

For example, Evans (1991), in the introductory chapter of Forestry Practice, makes the following statements:

Thinning practice in Britain initially followed the conservative principles employed in France and Germany but has become increasingly intensive 
to match closely removals from a stand with its growth capabilities. This has led to the concept of thinning at marginal intensity so that over the life of a crop the maximum amount of timber is removed in thinnings without significantly impairing overall yield of wood from a site.

This is further elaborated by Rollinson (1991): '(Thinning) is usually practised in order to provide more growing space for the remaining trees, to increase the total yield of usable timber over the life of the stand, and to provide an intermediate yield of timber'. Similarly, Hibberd (1989) states that: 'In Britain, there are three main types of forestry. The first of these is forestry undertaken with the primary aim of producing timber; the plantations and woods concerned are often referred to as "traditional forestry".' Crowther et al. (1991) argue that: 'Much forestry planting will have as its main objective the production of timber but there will be other important objectives concerned with landscape, conservation, recreation, sporting and shelter which may result in some reduction in timber producing capacity. Sometimes, such objectives will be paramount but rarely to the entire exclusion of timber production.' Under the 'new perspectives' being advocated in the United States, the emphasis would not be on timber production and maximizing yield. Instead, yield would be considered along with other equally important criteria for determining the nature and volumes of thinnings. However, it should be noted that in Great Britain, the objectives of thinning in coniferous plantations (primarily yield control) are different from those in broadleaved stands (primarily selection for quality) (Rollinson, 1991). In practice, private forestry, particularly in the lowlands, may have a more genuine multipurpose approach, since aesthetic and sporting interests often play a major part in the management of woodlands (Hibberd, 1989).

Graham (1992) has argued that contrary to what silviculturalists might believe, the new perspectives are not incompatible with silviculture. $\mathrm{He}$ points out that as silviculture is concerned with the establishment and growth of forests to management objectives (Smith, 1962), silvicultural practices should already be concerned with the management of forest ecosystems and landscapes. Also, the use of multiple-use principles has already been recommended (Daniel et al., 1979) and, in some cases, practised, within silviculture. However, the techniques recommended by Daniel et al. (1979) do not seem to be used very widely.

Many of the above issues surrounding forest management could be avoided if an ecosystem approach to the management of forests was adopted. Rowe (1992) summarized a document produced by the Ontario Wildlife Working Group (Ontario Wildlife Working Group, 1991) which defined an ecosystem approach to forest management as:

- adopting an holistic view of the natural world,

- recognizing complexity and interconnections, 
- taking account of the dynamic nature and finite capacities of ecosystems,

- encouraging collaboration among all those whose activities affect ecosystems.

Taking such an approach involves a fundamental change in forestry philosophy: the ultimate aim of growing trees is no longer to provide the maximum return through harvesting them but to provide benefits for the community as a whole. The benefits from harvesting must therefore be assessed in relation to the benefits from not harvesting. In particular, Franklin (1989) has stressed that the 'biological legacies' left after harvesting are critical to the ecology of the succeeding stand. Rowe (1992) makes the important point that forests should be seen in the light of capital and interest. It is the interest that foresters should be seeking to obtain. Practices that rely on the exploitation of the capital cannot be sustainable, yet how many current forest practices either knowingly or unwittingly exploit capital reserves?

To a certain extent, elements of this philosophy have already been adopted through landscape plans. When the potential visual impact of forest cutting is controlled, there may be simultaneous inadvertent controls on a variety of processes operating at the stand scale. These include effects on some wildlife species and the susceptibility of stands to disturbance from natural factors such as windthrow. A number of studies have examined this aspect in detail (e.g. Forman and Godron, 1981; Franklin and Forman, 1987; Swanson et al., 1990; Hansen et al., 1991; Probst and Crow, 1991; Brooks and Grant, 1992a). In Great Britain, the role of landscaping has been primarily to integrate the timber crop into the landscape (Crowe, 1978; Lucas, 1991). Consequently, designing forest landscapes that 'look right' has been given priority. Unfortunately, what may be aesthetically pleasing to landscape designers is not necessarily good for forest ecosystems (nor is everyone in agreement over what constitutes an aesthetically pleasing landscape). While landscape design may contribute to the social rate of return (Price, 1989), it does not necessarily enhance the ecological value of the forest landscape (Probstl, 1992).

\section{Some precepts of 'new forest management'}

Brooks and Grant (1992a, c) suggest a number of precepts that should be used to guide future forest management. Briefly, these are:

1. An ecosystem perspective should form the basis of forest management systems.

2. The impact of different forestry practices needs to be considered at a range of scales, ranging from the stand to the landscape.

3. The effects of forest management decisions must be evaluated using ecologically relevant time scales. 
4. Management decisions should leave as many options as possible open to enable change (whether physical or society) to be accommodated.

5. In multiple-use forests, forestry management decisions should be reached in participation with all users, not just the foresters.

\section{Ecosystem perspectives}

The first precept has been examined in detail in this paper. It seems essential that to understand problems facing forestry, an ecosystem approach is required. Failure to do this has resulted in difficulties over the resolution of several problems, including the Sitka spruce 'bent top' phenomenon in South Wales and the decline of high-altitude Scots pine stands in central and southern Scotland. Where integrated ecosystem research has been undertaken, solutions have often been found, with direct consequences for silvicultural management practices. An example of this would be the recommendations for the management of silver fir stands in France and Italy (Paganucci, 1989; Becker, 1991). The decline of many stands was initially attributed to 'acid rain'. However, since then, it has become apparent that the stands were susceptible to drought because of excessive stocking levels.

\section{Landscape impacts}

Controlling the impact of forestry on the landscape is probably the precept that has been best developed to date. Landscape planning has been widely used, but often the objective of the planning has been to reduce the visual impact of operations. A much wider approach is required, with the provision of landscape scale ecological features, such as wildlife corridors. In this sense, Howard and Snellgrove (1992) have emphasized the need for some changes in the way the process of harvesting is approached. Rather than being an end in itself, they recommend that harvesting be seen as a tool by which prescribed management objectives can be reached. Harvesting is critical to stand manipulation and thereby landscape manipulation, and a well-planned harvesting schedule will enable the multiple objectives of a forest to be reached.

\section{Ecologically relevant time scales}

One of the biggest problems facing an ecologically-oriented manager is that of time scales. While commercial interests can be pin-pointed relatively easily, it is much more difficult to take into account the longer term factors. With sustainable ecosystem management, the interest must lie with the longterm feasibility of a particular forest practice. This means over several rotations. The losses of nutrients associated with a rotation have been evaluated for some areas, and these can be compared with the incoming nutrients from rain, dust, weathering and other sources. Where a deficit exists, the management practice is not sustainable without artificial inputs of fertilizer. 


\section{Options}

The concept that management decisions should leave open as many options as possible is based on risk assessment. Over a rotation, demands for particular wood products may change, and the degree of flexibility in the management practices is therefore important. There may also be changes in the physical characteristics of the site or changes in the management objectives (Rollinson, 1991). There is currently much speculation about climatic change. If climate does change rapidly in the next 50 years, then it is likely to be those stands or species with the least variation and greatest adaptation to current environmental conditions that will suffer the most.

\section{Participation}

The last precept is important and some progress has already been made. However, true participation of all interested parties rarely takes place when the primary motivation remains the production of timber. Such participation is not without problems (Wondelleck, 1988; Knopp and Caldbeck, 1990), although problems may have arisen in the past from the methods chosen. Generally, small group participation, involving a two-way dialogue, is seen as the best method of interaction (Gericke et al., 1992).

\section{SUSTAINABLE FORESTRY}

Much attention has been given to the term 'sustainable'. Sustainable management is a laudable aim, but just how much forestry is sustainable? Many assumptions are made, but the underlying research basis for stating that any particular practice is 'sustainable' is often very shaky. The concept has been poorly defined, with the World Commission on Environment and Development defining sustainable development as being 'to ensure that development meets the needs of the present without compromising the ability of future generations to meet their own needs'. This rather vague definition is different from those used in economics and ecology (Bradley and Lewis, 1992). For example, many problems have been experienced in fast-growing plantations that can be directly attributed to mineral deficiencies (e.g. Boardman, 1978; Will, 1978; Schlatter and Gerding, 1985; Stone, 1990). Clearly, some fast-growing plantations are unsustainable without artificial inputs of fertilizers, creating a situation whereby productivity may decrease as a result of attempts to maintain and enhance it (Rozenweig, 1971). In such situations, the natural carrying capacity of the land is exceeded, thereby violating the principle of sustainability. While pollution provided a convenient scapegoat for the tree declines that affected several areas in Europe in the 1980s, it now seems that poor forest management (particularly in relation to species selection) was equally, if not more, to blame (Innes, 1993). Similarly, the use of whole-tree harvesting may result in 
impoverishment of the nutrient pools and the value of leaving some large woody debris has been emphasized by a number of studies (e.g. Jurgensen $e t$ al., 1987; Pritchett and Fisher 1987; Graham et al., 1989).

Gale and Cordray (1991) have examined the concept of sustainability within the framework of the question of what should be sustained. They list eight different approaches and each of these has been examined separately. Whereas Gale and Cordray (1991) looked at the approaches from a North American perspective, this paper attempts to draw upon European examples.

\section{Dominant product sustainability}

This is probably the most common approach in British forestry. Particular species are emphasized because of their relatively high value when compared with other species. The forest ecosystem is then manipulated to provide the maximum yield of these species. The approach is oriented towards the dominant product, and emphasis on other aspects is reduced. This is not entirely consistent with the objectives of multiple-use forestry which, although much advocated as a policy, seems to be rather less implemented as a management practice. However, concentration on forest management solely in relation to timber production means that potential revenue is lost (McNeely, 1989), suggesting that there should be strong financial incentives for multiple-use forestry.

The use of monocultures of 'improved' Sitka spruce in Great Britain epitomizes this approach. The approach is based on the assumption that such practices are sustainable, an assumption that is becoming increasingly tenuous. Currently, there are few sites with more than two rotations of this species, yet potential problems have already been identified with restocking on some more infertile sites (e.g. Taylor, 1990). More investigations of the nutritional budgets associated with multiple rotations on infertile soils seem to be required before the sustainability of such plantations can be fully assessed.

A different issue has been investigated by Nyland (1992). In eastern North America, there are extensive stands of hardwoods. Many of these are secondary, even-aged stands, clear-felling having been practised during the initial phase of development at the turn of the century or earlier. However, high prices for sawlogs in the 1980s led to the selective felling of the best trees. As a result, many stands now consist of poor-quality stems and lowvalue species. The disturbance to the stands is such that their future as productive forest stands is in question. Consequently, the current extraction practices cannot be considered as sustainable.

\section{Community sustainability}

This approach is based on the needs of the people and communities supported by the forests. In advocating such an approach, priority is given to 
the undisturbed flow of forest products. Within Great Britain, emphasis has been on afforestation. As a result, there is little history of communities dependent on the forest industry. The creation of rural employment has been one of the arguments used in favour of afforestation (although other activities may actually be a much greater source of employment), and there will be a certain moral pressure to ensure that this employment is continued through a guaranteed supply of timber. However, given that a number of major forest product processing plants in Great Britain also depend on a regular supply of timber, protection of industrial investments may prove to be a stronger impetus to guaranteed supply than any society or community needs, particularly in a political environment governed by market forces.

\section{Human benefit sustainability}

Under this approach, forests are seen as a resource with the sole objective of providing benefits to people (although the nature of these benefits may be variable). By providing for these needs, the forest ecosystem may simultaneously be maintained. The human benefit approach is central to the concept of multiple-purpose forestry. It is important to recognize that the value attributed to particular uses is likely to change over time, both as a result of changing priorities and as a result of changes in the nature of the forest itself (Walters, 1986).

\section{'Global Village' sustainability}

This approach has been emphasized in recent years in relation to the importance of forests as carbon sinks and global climate regulators. However, when applied at a local scale, the concept is rather more difficult to apply. It is uncertain whether a forest manager in, for example, Great Britain, is likely to appreciate the role of a hardwood stand as a carbon sink (if indeed it is) when deforestation is continuing at such a rate elsewhere.

\section{Self-sufficient sustainability}

This approach is based on the premise that a healthy forest ecosystem is self-sustaining, requiring no extra inputs of, for example, fertilizers, herbicides or insecticides. As Gale and Cordray (1991) state, the goal of such an approach is the long-term integrity of the forest ecosystem. The approach can accommodate harvesting, but this is limited to a much lower level than the human benefit or dominant product approaches. It encompasses some of the new ideas on forest stewardship, but falls foul of any approach that involves a land rent. 
Ecosystem type sustainability

The ecosystem type approach is related to the preservation of large-scale ecosystems (wetlands, forests, desert) rather than more specific components of each. Forests would be seen as a type of ecosystem that should be sustained, but the precise nature of these forests is not an issue. The concept of ancient woodland falls under this approach, whereby a forest ecosystem type is defined by its continuity over a (limited) period of time. The normal requirement for felled forest to be replaced by forest indicates the widespread application of this approach in Great Britain. However, such an approach is not seen as favourable by all parties: there would, for example, be considerable interest in some quarters in allowing parts of the flow country to be returned to moorland.

\section{Ecosystem insurance sustainability}

A pattern of forest reserves combined with productive forests is the basis for this approach. The forest reserves are designed to protect the sustainability of the forest against major disasters, but should not necessarily be seen as spatially discrete entities. The approach reflects the recognition that ecological disasters are possible and the approach may have been adopted unwittingly in some cases. For example, the decline of tree health in a number of areas may be more related to long-term management problems rather than to the more frequently (and conveniently) blamed 'acid rain'. However, just how this approach is likely to protect the sustainability of the ecosystems against problems such as long-term nutrient depletion seems to be a little unclear.

\section{Ecosystem-centred sustainability}

Of the different approaches, this is by far the most environment-oriented. The continuation of natural forest ecosystems is emphasized and there is a strong preservation basis in the approach. Many nature reserves adopt this approach. This approach is, however, questionable as the ecosystem must be seen in relation both to its surroundings and to its history. For example, the management of pine forest in the Abernethy reserve in Scotland has created problems for the Royal Society for the Protection of Birds: control of deer and a reduction in the number of predators (foxes and crows) seems to be required if the forest ecosystem is to be maintained and enhanced.

These different approaches to sustainability are not all mutually exclusive. It is possible that more than one approach could be adopted in a particular situation: the challenge lies in identifying an appropriate balance.

The concept of sustainability implies a degree of knowledge about the dynamics of forest ecosystems that simply does not exist. While Brooks and 
Grant (1992a) have emphasized the importance of considering forest conditions over multiple rotations, such a long-term view has rarely, if ever, been employed in relation to afforestation programmes. At most, concern has been expressed about potential second-rotation problems: the long-term sustainability of such stands has not been considered. Restructuring of many upland forests is now underway in Great Britain, and production objectives are being made within the constraints of an environmentally sensitive framework. However, the restructuring does not appear appear to take into account the long-term sustainability of the forest.

Even the concept of forest ecosystems is open to discussion; mathematically, an ecosystem can be defined as a set, but this immediately brings into question where the boundaries are drawn. As discussed below, this is frequently a problem of scale. However, it is also a problem of definition. A frequent definition of an ecosystem is as the habitat for a specific group of organisms. For example, foresters might consider a forest ecosystem as being where trees grow. Consequently, forest ecosystem research tends to be focused on trees and the factors that influence them. This can clearly be seen in some of the forest 'ecosystem' studies currently being conducted in Europe. However, to an entomologist, a forest ecosystem is a very different entity. This can be neatly illustrated by comparing what a tree physiologist and an ornithologist might consider to be a forest ecosystem. For the former, the stand or even the individual tree would be sufficient. For the latter, the stand could not represent the forest ecosystem, because birds depend on larger areas.

Rowe (1992) recognizes a hierarchical pattern of ecosystem arrangement, with foresters being concerned with the smallest level of three-dimensional space. He emphasizes that living and inanimate parts should not be separated and the division between the organisms and their less important environment is false. This seems to provide a useful framework for further work on the interactions between forest management and the concept of forest ecosystems.

\section{BIODIVERSITY IN FORESTS}

Major problems surround what is meant by biodiversity. At its simplest, the maintenance of biodiversity concerns the preservation of all species that should be present in a given habitat type. At its most complex, it entails the maintenance of the genetic diversity within a population. As global biodiversity has been declining (Wilson and Peters, 1988), the need for such action is clear. For forestry, the easiest way of maintaining biodiversity is to maintain the habitats that comprise a forest. When adopting such a view, it is important to consider forests at a landscape scale (Hunter, 1990; Oliver 1992). Stand regeneration is achieved in a mosaic format when viewed at a landscape level. This is based on the principle that a forest is a dynamic entity, 
subject to periodic disturbances at a variety of scales. The old concept, that a natural forest consists of undisturbed trees that form a 'climax ecosystem' now seems to be inappropriate to most forest situations. While it is almost impossible to recreate the natural situation (whatever that was), it is possible to increase structural diversity within a forest by specific management procedures (Boyce, 1985; O'Hara and Oliver, 1991; Oliver et al., 1992; Salwasser, 1992). This represents a compromise between the extreme positions held on the one hand by some commercial foresters and on the other by extreme ecological groups (Namkoong, 1992). It may also be an important step towards maintaining forest productivity, since there are numerous examples of cases where productivity can be enhanced by increased diversity (Franklin et al., 1989).

Diversity is a measurable phenomenon and a variety of different indices have been developed to describe the diversity of an area (Burton et al., 1992). Most of these distinguish between the diversity at a site and the diversity in a landscape mosaic. Diversity in forests can be increased, and changes will have significant effects on biodiversity (Harris, 1984; Maser, 1988; Hunter, 1990).

Namkoong (1992) maintained that encompassing the principles of biodiversity maintenance within forestry would involve the synthesis of numerous fragmented research fields and management techniques. In doing this, he suggested that forestry research might be reunited into a single field, a problem that is identified elsewhere in this paper. Three concepts were emphasized by Namkoong (1992):

1. Biodiversity involves all life forms and a variety of structures that exist at multiple levels of organization.

2. The dynamics of diversity are poorly understood but involve complex interactions among individuals, species and communities.

3. The structure of biodiversity has changed and will change according to our choice of action or inaction.

Under such concepts, the idea that all alleles, all individuals, all populations, all species or all communities can be preserved becomes redundant, as such preservation would be impractical.

The problem has also been approached by the Society of American Foresters who have issued a position statement on biological diversity in forest ecosystems (Society of American Foresters, 1991). They defined biological diversity as 'the variety and abundance of species, their genetic composition, and the communities, ecosystems, and landscapes in which they occur' adding that it also referred to 'ecological structures, functions, and processes at all these levels'. They recognized that the use of practices such as monocultures seriously reduced biological diversity. They linked diversity to sustainable forest utilization, arguing that the maintenance of the composition and structural diversity of the forest (but not necessarily the 
stand) was essential for the continuation of those ecological processes that control the sustainable use of a forest. They emphasized the importance of scale: clear-cutting a stand may increase the diversity of a forest; clearcutting the forest will reduce it. As in most situations where ecology and economics meet, it seems that the problem is one of balance. The Society of American Foresters' position statement makes a number of recommendations. These are:

1. Plans for managing forests should include strategies to conserve and enhance biological diversity consistent with landowner objectives.

2. Because biological diversity affects many dimensions of human life, forest planners should consult with other natural resource professionals, social scientists, local and state government planners, and civic and political leaders to ensure that all human needs are being considered.

3. University curricula for forestry and other resource management professions should incorporate knowledge about biological diversity.

4. Continuing education programs should be developed and offered to practising natural resource professionals to extend their knowledge about biological diversity. Biological diversity also should be included in environmental education programs for the general public.

5. The current polarization between biological and economic values is intensified by the lack of scientific information, making it difficult to develop good public policy. Both values are important; hence, more scientific knowledge is needed about biological diversity, including how it can be protected while providing for other values.

6. Major new sources of funding should be developed to support research in the basic biology and ecology of forests; biological diversity; and the development of management strategies and technologies that sustain forest productivity and protect biological diversity. Conservation, industrial, and professional organizations should be encouraged to support funding for forestry research in these areas.

\section{DIFFERENT FOREST TYPES}

It is perhaps significant that the recent movement towards revisions of management practices in America largely originated in the north-west. Here, it seems to have been the clear-cutting of virgin forest that created the initial impetus for the proposals. Issues such as habitat preservation for the northern spotted owl Strix occidentalis ssp. caurina (in the west) and the red-cockaded woodpecker Picoides borealis (in the east) came later. While it is relatively easy to recommend a more ecologically sympathetic approach to the management of virgin forests, it is not necessarily appropriate to recommend the same principles for the management of plantation forestry in other parts of the world. 
Three types of forest ecosystem exist: natural and undisturbed, artificial and highly disturbed and a third, somewhere in the middle, that relies on the exploitation of natural forests. Rowe (1992) emphasizes that the approaches to these should be different, with timber plantations having little relevance to the maintenance of biodiversity. He considers that the management of semi-natural ecosystems is critical, since it is these that form a major part of the current landscape (in Canada). In discussing such systems, he argues that the maintenance of the ecosystem integrity is more important than the yield of wood. In Great Britain, there has been a tendency to view semi-natural Scots pine (Caledonian) and broadleaved forests as being more suitable for multipurpose forestry than Sitka spruce plantations. However, this need not necessarily be the case, and McIntosh (1991) has demonstrated how careful planning at the second rotation stage can greatly enhance the amenity and conservation value of a forest - in this case Kielder Forest.

The recognition of different forest types provides a means of recognizing the value of different types of forestry. It seems clear that different types of forest should be treated in different ways and should be subject to different forms of control. To a certain extent this is already happening in some countries, as the multiplicity of forestry grant schemes in Great Britain illustrates.

There is clearly a need to attach different values to different basic types of woodland. A premise of the 'new perspectives' is that such values should be based on how closely the management seeks to emulate natural processes. From an ecological viewpoint, a broadleaved semi-natural woodland has greater ecological value than a plantation of exotic conifers, and this needs to be reflected in the economic (as opposed to commercial) valuation. The costs of such an approach have been examined in a number of studies, including those by Lorrain-Smith $(1982,1988)$, Pryor and Savill (1986) and Spilsbury (1990).

\section{A RESEARCH FRAMEWORK}

The new management policies claim to be based on the scientific analysis of forest ecosystem processes. However, although quite a lot is known about how forest ecosystems function, there are still an uncomfortable number of gaps in our basic understanding of the system. There are also major gaps in the application of this ecological knowledge to management practices. Consequently, there has been a growing feeling that forestry research is poorly oriented. This is particularly true for applications of research to ecosystem-oriented management. For example the National Research Council of the United States of America (National Research Council, 1990) has stated that: 'Although much good research is now in progress within the forestry research community, in aggregate, forestry research is inadequate to meet society's needs. Forestry research must improve in quality and at the 
same time broaden its scope if social issues are to be addressed adequately.' The National Research Council identified six major issues related to forest research that needed to be addressed:

1. interactions between forests and climate,

2. loss of biological diversity,

3. growing demands for wood and wood products,

4. increasing demand for the preservation of 'pristine' areas,

5. sustainable production of wood products integrated with all the other products and services obtained from forests, and

6. maintenance of the health of forests nationally and globally.

Although these issues are applicable outside America, a cursory look through the research agendas of most European forestry organizations does not reveal a concentration of research and policy applications on these themes. Instead, the over-riding concern still appears to be with the production of timber. For example, in the year ended March 1990, only 5.6 per cent of research expenditure by the Forestry Commission was devoted to wildlife and conservation, compared with 10.7 per cent on tree improvement and 31.2 per cent on silviculture (Forestry Commission, 1991).

The concern for timber production should not be over-criticized. There is clearly a need for timber and timber products, but it is important to place this need within the context of other needs. Multipurpose forestry has recently been much used as a policy framework, but a critical appraisal of policies claiming to serve multipurpose forestry reveals that very few achieve this aim and the adoption of such a policy presents a major challenge (Behan, 1990). Instead, wood production remains the central theme and other aspects are added only when they do not significantly affect production. Uses such as the maintenance of biological diversity and the regulation and mitigation of climatic change are seen as important but are difficult for the practising forester to value (Brooks and Grant, 1992a).

Current research orientation is becoming increasingly applied, but shortterm benefits are often incompatible with the long-term research needs of the industry. The National Research Council of the USA saw five areas where research needed to be strengthened:

1. biology of forest organisms,

2 ecosystem function and management,

3. human-forest interactions,

4. wood as a raw material, and

5. international trade, competition and co-operation.

These compare with the 10 forestry topics most in need of further research identified in Canada (Anon., 1992a, 1992b). In order of priority (the priority given by Anon. (1992b) is used rather than the priority order cited by Anon. (1992a)), these were: 
1. integrated resource management and decision support,

2. pest and weed management, and alternatives to chemicals,

3. environmental effects of forest management,

4. ecological knowledge for intensive forest management,

5 . forest growth and yield data,

6. increased productivity, tree improvement, and regeneration,

7. forest inventory and site classification,

8. silviculture and harvesting methods, and cost reduction,

9. forest fire management and control, and

10. mixed wood management.

In addition, wood processing and the development of new products were also seen as important areas requiring further research. The pest and weed theme was emphasized by Plochman (1992) in the European context. He recommended that no herbicides should be used and that insecticides and fertilizers should only be applied rarely. This would represent a marked change for British forestry practices, where herbicides are widely used during the establishment phase.

There has also been a fundamental shift in the emphasis of research in forestry (Brooks and Grant, 1992a). This change has involved a shift from opponents of forestry having to demonstrate that a particular practice has adverse ecological effects to foresters having to demonstrate that a particular practice does not have adverse ecological effects. Recent public enquiries into the effect of afforestation schemes clearly indicate that forest research has moved to a defensive position, a change that can hardly be unexpected given the manner with which some environmental issues have been dealt with (e.g. water acidification).

The problems associated with the definition of a research agenda have been discussed by Brooks and Grant (1992b). They argue that the adoption of an ecosystem approach is essential but that this is hindered by inadequate terminology. While terms such as old-growth and pole-stage are widely used, there is little to describe the multiplicity of intermediate states. Such terms are primarily restricted to individual stands; when attempts are made to describe the state of a landscape, even more problems are apparent. They emphasize that ecosystems also comprise stocks (viewed as the capital of the system by various authors, e.g. El Serafy (1991), Costanza et al. (1991), Brooks and Grant (1992b) and Rowe (1992)) and flows (the yield or revenue from the ecosystem). While this has been long recognized in forestry, with harvesting levels and stocking levels being carefully linked, the concept has not been applied to components of the ecosystems other than trees. However, increasingly, this is being done in relation to environmental problems, with, for example, some of the better attempts to quantify carbon sequestration by forests fully integrating ecological and economic aspects of the problem. Methods for doing this have been known for some 
time (e.g. Odum, 1983) and formal methods are described by Hannon (1991).

\section{ETHICAL STANDARDS}

Another major issue that has recently received attention is that of ethical practices in forestry. This is closely related to the proposals for ecosystembased forest management, as it is argued that the commercial exploitation of forests purely for timber is unethical. The onus is being placed on individual forest managers to operate in ecologically sensitive ways, although it is perhaps a little naive to hope that foresters will be able to persuade forest owners that a less commercially-oriented approach to forestry is desirable.

The subject of ethical standards has received considerable attention in the American literature. The Society of American Foresters established a Land Ethic Task Force in 1991. The Task Force made two recommendations which have now been accepted by the membership. These are that the preamble to the existing code of ethics starts with the statement that: 'Stewardship of the land is the cornerstone of the forestry profession' and that Canon 1 of the Code of Ethics is that: 'A member will advocate and practice land management consistent with ecologically sound principles.' By ecologically sound principles, it is meant that the objectives of the owners of the land are met without causing ecological damage (Craig, 1992). The emphasis here is on the prerogative of the owner to decide the management practices, but within certain prescribed limits (those not causing ecological damage). This presents a considerable problem as it is difficult, if not impossible, to identify what constitutes ecological damage. The term damage has an economic overtone, but it is unlikely that ecologists could place economic values on every component of a forest ecosystem. Exactly the same problem surrounds the issue of critical loads theory, which has been concerned with reducing pollution to a level that has no adverse effects on the most sensitive part of an ecosystem. In practice, this definition has been discarded, as the emphasis on trout in the forestry-water acidification debate illustrates.

Namkoong (1992) has attempted to define a biodiversity ethic. As with other ethical aspects of forestry, the choice revolves around a need for the adequate valuation of ecosystem components. Assumptions have to be made about whether an organism has inherent value and, if so, at what level of organization management for preservation must be undertaken. Taking an example from Great Britain, how much forest management should be undertaken for a species such as the golden oriole, right on the edge of its range in southern Great Britain, when the species can be found much more frequently throughout the remainder of its range?

The new ethical standards for forestry being proposed by several different organizations should not be seen as a direct attack on existing practices. 
Instead, standards evolve in relation to the function of the forester (Ruh, 1992). By dropping the maxim of maximum timber yield in favour of maximum benefit, the forester is not abandoning financial good sense, as many benefits can be valued (c.f. Benson and Willis, 1992; Willis and Garrod, 1992). However, in practice, the valuation of non-timber benefits remains an area where considerable work is still required (House of Commons' Committee of Public Accounts, 1987).

\section{CONCLUSIONS}

Within Great Britain, the forest industry has sometimes adopted a reactive role when confronted with criticism. Attempts have been made to adopt a more proactive approach, but these have not always been successful. As a result, foresters have sometimes been consigned to the sidelines when certain issues have been discussed. Foresters should be at the centre of debates on issues such as biodiversity and sustainability. That they are not reflects not only a lack of expertise in these areas, but is suggestive of a lack of concern. Consequently, some of the criticism may be justified.

It is clear that the adoption of an ecosystem approach to forest management will result in higher short-term commercial costs to forest managers. Whether these costs will be recouped in the long-term is uncertain. However, when the losses of timber revenues are set against the benefits obtained from managing the forest as an ecosystem, a more equitable situation may be apparent. This requires two things. First, a valid method of valuing non-timber benefits must be designed. Second, a means of transferring the costs of these benefits from the beneficiaries to the forest owners needs to be devised. In Great Britain, there is already a system of grant-aid for forest management that is sympathetic to multiple-purpose forestry. However, this needs to be greatly enhanced, possibly through a reduction in the subsidies for commercial forestry.

To many, the claims being made by special interest groups are without validity, as jurisdiction of land use and land management should lie with the owners. It has been beyond the scope of this paper to examine this controversial yet crucial issue. However, it seems clear that the individual or group most benefiting from particular management practices should pay for them (Brandl, 1992). Such a method has been adopted in Italy, but it has only focused on particular aspects of forest benefits, such as timber production or conservation value, and the multiple uses of forests have not been taken into account (Pettenella, 1989). A variety of methods of obtaining revenues from non-timber aspects of forestry are currently being investigated, but while some are relatively easy to value (e.g. sporting), others are much more difficult (e.g. provision of wildlife habitat).

An ecosystem-based approach to forest management has been proposed as a means of achieving a number of goals, including the political aims of 
sustainability and maintenance of biodiversity. Given that political aims in a democratic situation theoretically represent the will of the majority, there is a need to recognize the divergence of opinion that has occurred in recent years over forest management practices. While these changes may be difficult to accommodate, Brooks and Grant (1992a) make the following observation: 'Forest managers must recognise that the findings of forestry science, cumulated over 20 to 40 years - and closely associated with results in other areas of science - are forcing us to rethink our approaches to management.' The new approaches being proposed are not incompatible with many of the silvicultural techniques already being practised in some parts of the world. It remains to be seen how many of these are either desirable or appropriate for British plantation forestry. Research has answered many existing questions but has also pointed to some shortcomings in current management practices. These urgently need to be addressed, as do the considerable number of areas where research is currently inadequate.

The following points seem to be the most important of those raised in this paper, but are also likely to be the most controversial. Forests could be seen as ecosystems and managed according to ecosystem principles. This requires reliable information on how ecosystems function; currently, many 'ecological principles' are too vague to be incorporated into management. Timber that is produced solely as a commercial crop could be treated as such, and subjected to market forces; many other resources (outside the general area of agriculture) are already treated in this fashion. When forests are treated as ecosystems, the exploitation of one resource (e.g. timber) should not degrade another (e.g. biodiversity). This will require the identification of all the potential resources that a forest represents. In particular, it is important to establish the value of forest ecosystems to bodies other than the more vociferous pressure groups. Landscape management could have priority when drawing up long-term forest plans. However, landscape management should not be left to landscape designers. Rather, all interested groups should be involved at the planning stage.

It is perhaps useful to finish with a reminder of what the 'new perspectives' are about: 'New perspectives is not a set of new silvicultural practices or new analytical tools. It is an attitude about change and how we are going to manage our natural resources in the future. ... It is the creation of a management environment that is open to new ideas, and things yet to come' (Cargill, 1992).

\section{REFERENCES}

Anon. 1992a Forest research priorities in Canada, 1991. An overview for the Canadian Council of forest ministers prepared by the Forest Research Advisory Council of Canada in co-operation with the Forestry Research Advisory Committees in the provinces and territories. For. Chron. 68, 121-125. 
Anon. 1992b Forestry Research Advisory Council of Canada. Annual Report for 1991. For. Chron. 68, 517-521.

Arbeitsgruppe Waldbau des Schweizerischen Forstvereins. 1990 Spannungsfeld Waldbau - Nature- und Landschaftsschutz. Schweiz. Z. Forstwes. 141, 23-54.

Avery, M.I. and Leslie, R. 1990 Birds and Forestry. T. \& A.D. Poyser, London.

Beasley, J.L. 1992 National trends and the art of silviculture. In Getting to the future through silviculture - Workshop proceedings. Murphy, D. (compiler). United States Department of Agriculture Forest Service, Intermountain Research Station, General Technical Report INT-291. pp. 1-4.

Becker, M. 1991 Impact of climate, soil and silviculture on forest growth and health. In French Research into Forest Decline. Landmann, G. (ed.). Ecole Nationale du Génie Rurual, des Eaux et des Forêts, Nancy. pp. 23-38.

Behan, R.W. (1990 Multiresource management: a paradigmatic challenge to professional forestry. J. For. 88, 12-18.

Benson, J.F. and Willis, K.G. 1992 Valuing informal recreation on the Forestry Commission estate. Forestry Commission Bulletin No. 104. HMSO, London.

Boardman, R. 1978 Productivity under successive rotations of Radiata pine. Aust. For. 41, 177-179.

Boyce, S.G. 1985 Forestry decisions. United States Department of Agriculture, Forest Service, General Technical Report SE-35. Southern Forest Experiment Station, Asheville.

Bradley, D.P. and Lewis, B.J. 1992 Ecological economics. Integrating natural and. social dimensions. J. For. 90(2), 30-33.

Brandl, H. 1992 Wirtschaftliche Moglichkeiten der Forstbetriebe. Forstwiss. Centralb. 111, 269-281.

Brooks, D.J. and Grant, G.E. 1992a New approaches to forest management. Background, science issues, and research agenda. J. For. 90(1), 25-28.

Brooks, D.J. and Grant, G.E. 1992b New approaches to forest management. Background science issues and research agenda. J. For. 90(2), 21-24.

Brooks, D.J. and Grant, G.E. 1992c New perspectives in forest management: background, science issues, and research agenda. United States Department of Agriculture Forest Service, Pacific Northwest Research Paper PNW-RP-456.

Burton, P.J., Balisky, A.C., Coward, L.P., Cumming, S.G. and Kneeshaw, D.D. 1992 The value of managing for biodiversity. For. Chron. 68, 225-237.

Cargill, G. 1992 Some thoughts on new perspectives. In Rocky Mountain New Perspectives. Proceedings of a regional workshop. Bartlett, E.T. and Jones, J.R. (eds). United States Department of Agriculture Forest Service, Rocky Mountain Forest and Range Experiment Station, General Technical Report RM-220, 22-23.

Clark, R.N. and Stankey, C.G. 1991 New forestry or new perspectives? The importance of asking the right questions. Forestry Perspectives 1, 9-13.

Costanza, R., Daly, H. and Bartholomew, J. 1991 Goals, agenda, and policy recommendations for ecological economics. In Ecological Economics: The Science and Management of Sustainability. Costanza, R. (ed.). Columbia University Press, New York, 1-20.

Craig, R. 1992 Land ethic canon proposal. A report from the Task Force. J. For. 90, $40-41$.

Crowe, S. 1978 The landscape of forests and woods. Forestry Commission Booklet No. 44. HMSO, London.

Crowther, R.E., Low, A.J. and Tabbush, P.M. 1991 Establishment and tending. In Forestry Practice. Forestry Commission Handbook No. 6. Hibberd, B.G. (ed.). HMSO, London, 41-80.

Daniel, T.W., Helms, J.A. and Baker, F.S. 1979 Principles of Silviculture. McGrawHill, New York. 500pp. 
El Serafy, S. 1991 The environment as capital. In Ecological Economics: the Science and Management of Sustainability. Costanza, R. (ed.). Columbia University Press, New York, 168-175.

Evans, J. 1991 Forestry in Britain. In Forestry Practice. Forestry Commission Handbook No. 6. Hibberd, B.G. (ed.). HMSO, London, 1-9.

Forestry Commission 1991 Report on Forest Research 1990. HMSO, London.

Forman, R.T.T. and Godron, R. 1981 Patches and structural components for a landscape ecology. BioScience 31, 733-739.

Franklin, J.F. 1989 Toward a new forestry. Am. For. 95, 37-44.

Franklin, J.F. 1990 Thoughts on applications of silvicultural systems under new forestry. Forest Watch 10, 8-11.

Franklin, J.T. and Forman, R.T.T. 1987 Creating landscape patterns by forest cutting: ecological consequences and principles. Landscape Ecol. 1, 5-18.

Franklin, J.F., Perry, D.A., Schowalter, T.D., Harmon, M.E., McKee, A. and Spies, T.A. 1989 Importance of ecological diversity in maintaining long-term site productivity. In Maintaining the Long-term Productivity of Pacific Northwest Forest Ecosystems. Perry, D.A., Meurisse, R., Thomas, B., Miller, R., Boyle, J., Means, J., Perry, C.R. and Powers, R.F. (eds). Timber Press, Portland, 82-97.

Gale, R.P. and Cordray, S.M. 1991 What should forests sustain? Eight answers. J.For. 89(5), 31-36.

Gane, M. 1992 Sustainable forestry. Commonw. For. Rev. 71, 83-90.

Gayer, K. 1889 Der Waldbau. 3. Auflage Berlin.

Gericke, K.L., Sullivan, J. and Wellman, J.D. 1992 Public participation in National Forest planning. Perspectives, procedures, and costs. J. For. $\operatorname{90}(2)$, 35-38.

Gillis, A.M. 1990 The new forestry: an ecosystem approach to land management. BioScience 40, 558-562.

Graham, R.T. 1992 The practice of silviculture and new perspectives. In Getting to the future through silviculture - workshop proceedings Murphy, D. (compiler), United States Department of Agriculture Forest Service Intermountain Research Station, General Technical Report INT-291, 19-22.

Graham, R.T., Harvey, A.E. and Jurgensen, M.F. 1989 Effect of site preparation on survival and growth of Douglas-fir (Pseudotsuga menziesii Mirb. Franco) seedlings. New Forests 3, 89-989.

Gregg, N.T. 1992 Sustainability and politics: The cultural connection. J. For., 90(7), $17-21$.

Hannon, B. 1991 Accounting in ecological systems. In Ecological Economics: the Science and Management of Sustainability. Constanza, R. (ed.). Plenum Press, New York, 234-252.

Hansen, A.J., Spies, T.A., Swanson, F.J. and Ohmann, J.L. 1991 Conserving biodiversity in managed forests: lessons from natural forests. BioScience 41 , 382-392.

Harris, E.H.M. and Harris, J.A. 1991 Wildlife Conservation in Managed Woodlands and Forests. Basil Blackwell, Oxford.

Harris, L.D. 1984 The Fragmented Forest: Island Biogeography Theory and the Preservation of Biotic Diversity. University of Chicago Press, Chicago.

Hart, C. 1991 Practical Forestry for the Agent and Surveyor. 3rd edition. Alan Sutton, Stroud.

Heyer, C. 1841 Die Waldertragsregelung. Giessen.

Hibberd, B.G. 1989 The need for advice. In Urban forestry practice Hibberd, B.D. (ed.). Forestry Commission Handbook No. 5. HMSO, Edinburgh, 10-17.

Hibberd, B.G. (ed.). 1991 Forestry practice. Forestry Commission Handbook No. 6. HMSO, London. 
Hornsmann, E. 1958 Allen hilft der Wald. BLV Verlagsgesellschaft, Munchen, $259 \mathrm{pp}$.

House of Commons' Committee of Public Accounts 1987 Forestry Commission: Review of objectives and achievements. Twelfth Report of the Committee of Public Accounts for the Session 1986-87. HMSO, London.

Howard, J.O. and Snellgrove, T.A. 1992 Putting the ' $\mathrm{H}$ ' word into perspective. In Getting to the future through silviculture - workshop proceedings. Murphy, D. (compiler). United States Department of Agriculture Forest Service Intermountain Research Station, General Technical Report INT-291, 25-28.

Hunter, M.L. 1990 Wildlife, Forests and Forestry: Principles of Managing Forests for Biological Diversity. Prentice Hall, Englewood Cliffs.

Innes, J.L. 1993 Forest Health: Its Assessment and Status. Commonwealth Agricultural Bureau, Oxford, in press.

Jurgensen, M.F., Larsen, M.J., Graham, R.T. and Harvey, A.E. 1987 Nitrogen fixation in woody residue of Northern Rocky Mountain conifer forests. Can. J. For. Res. 17, 1283-1288.

Knopp, T.B. and Caldbeck, E.S. 1990 The role of participatory democracy in forest management. J. For. 16, 197-212.

Landolt, E. 1895 Der Wald, seine Verjüngung, Pflege und Benutzung. Friedrich Schulthess, Zürich. $421 \mathrm{pp}$.

Lorrain-Smith, R. 1982 An economic analysis of silvicultural options for broadleaved woodland. Commonwealth Forestry Institute Occasional Paper 19, vol. II.

Lorrain-Smith, R. 1988 The Economic Effects of the Guidelines for the Management of Broadleaved Woodlands. Timber Growers United Kingdom, London.

Lucas, O.W.R. 1991 The Design of Forest Landscapes. Oxford University Press, Oxford.

Mantel, W. 1961 Wald und Forst. Wechselbeziehungen zwischen Natur and Wirtschaft. Rohwohlt, Hamburg. 149 pp.

Maser, C. 1988 The Redesigned Forest. R. \& E. Miles, San Pedro.

McIntosh, R. 1991 Planning for the second rotation. In Forestry practice. Hibberd, B.G. (ed.) Forestry Commission Handbook No. 6. HMSO, London, 211-222.

McNeely, J.A. 1989 Economics and Biological Diversity: Developing and Using Economic Incentives to Conserve Biological Resources. Columbia University Press, New York.

Namkoong, G. 1992 Biodiversity - issues in genetics, forestry and ethics. For. Chron. 68, 438-443.

National Research Council. 1990 Forestry Research: A Mandate for Change. National Academy Press, Washington DC.

Nyland, R.D. 1992 Exploitation and greed in eastern hardwood forests. J. For. 90(1), 33-37.

O'Hara, K.L. and Oliver, C.D. 1991 Silviculture: achieving new objectives through stand and landscape management. West. Wildlands 17, 28-33.

Odum, H.T. 1983 Systems Ecology: An Introduction. John Wiley and Sons, New York.

Oliver, C.D. 1992 A landscape approach. Achieving and maintaining biodiversity and economic productivity. J. For. 90(9), 20-25.

Oliver, C.D., Berg, D.R., Larsen, D.R. and O'Hara, K.L. 1992 Integrating management tools, ecological knowledge, and silviculture. In New perspectives for watershed management. Naiman, R. (ed.). Springer-Verlag, New York.

Ontario Wildlife Working Group 1991 Looking Ahead: A Wildlife Strategy for Ontario. Ministry of Natural Resources, Wildlife Policy Branch, Toronto.

Paganucci, L. 1989 Sperimentazione sulla densità di impianto delle abetine di Vallombrosa. Ital. For. Mont. 44, 30-44. 
Parson, E.A., Haas, P.M. and Levy, M.A. 1992 A summary of the major documents signed at the earth summit and the global forum. Environment 34(8), 12-15, 34-36.

Pecore, M. 1992 Menominee sustained-yield management. J. For. 90(7), 12-16.

Peterken, G.F., Ausherman, D., Buchenau, M. and Forman, R.T.T. 1992 Oldgrowth conservation within British upland conifer plantations. Forestry 65, 127-144.

Pettenella, D. 1989 Dall'economia dell'azienda forestale finalizzata all'autoconsumo all'economia dei sistemi forestali produttori di beni multipli ad uso collettivo. In Problemi economici nei rapporti tra agricoltura e ambiente. Proceedings of the XXV Study Convention of SIDEA, Ancona, Italy, October 1988. Quaderni della Rivista di Economia Agraria (1989) No. 12, 357-70.

Plochman, R. 1992 The forests of central Europe. A changing view. J. For. 90(6), $12-16$ and 41.

Price, C. 1989 The Theory and Application of Forest Economics. Basil Blackwell, London.

Pritchett, W.L. and Fisher, R.F. 1987 Properties and Management of Forest Soils. 2nd edition. John Wiley, New York. 494 p.

Probst, J.R. and Crow, T.R. 1991 Integrating biological diversity and resource management. J. For. 89(2), 12-17.

Probstl, U. 1992 Naturschutz in Deutschland. Geschichte, Strategien und Perspektiven. Forstwiss. Centralbl. 111, 293-306.

Pryor, S.N. and Savill, P.S. 1986 Silvicultural Systems for Broadleaved Woodland in Britain. Commonwealth Forestry Institute, University of Oxford, Occasional Paper 32.

Rollinson, T.J.D. 1991 Management for timber production. In Forestry Practice. Hibberd, B.G. (ed.). Forestry Commission Handbook No. 6. HMSO, London, p. 147-161.

Rowe, J.S. 1992 The ecosystem approach to forestland management. For. Chron. 68, 222-224.

Rozenweig, M.L. 1971 Paradox of enrichment: destabilization of exploitation ecosystems in ecological time. Science 171, 385-387.

Ruh, H. 1992 Wald und Gesellschaft: Ethische Aspekte. Schweiz. Z. Forstwes. 143, $877-884$.

Salwasser, H. 1990 Gaining perspective: forestry for the future. J. For. 88, 32-38.

1992 The challenge of new perspectives. In Rocky Mountain New Perspectives. Proceedings of a regional workshop. Bartlett, E.T. and Jones, E.R. (eds). United States Department of Agriculture Forest Service, Rocky Mountain Forest and Range Experiment Station, General Technical Report RM-220, 3-7.

Schlatter, J. and Gerding, V. 1985 Deficiencia de boro en plantaciones de Pinus radiata D.Don en Chile. I. Distribucion y origen. Bosque 6, 24-31.

Smith, D.M. 1962 The Practice of Silviculture. John Wiley, New York. 578 pp.

Society of American Foresters 1991 Biological Diversity in Forest Ecosystems. Society of American Foresters, Bethesda.

Spilsbury, M.J. 1990 Economic prospects for natural management of woodlands in the UK. Forestry 63, 379-390.

Stone, E.L. 1990 Boron deficiency and excess in forest trees: A review. For. Ecol. Manage. 37, 49-75.

Swanson, F.J., Franklin, J.F. and Sedell, J. 1990 Landscape patterns, disturbance, and management in the Pacific Northwest, USA. In Changing Landscapes: An Ecological Perspective. Zonneveld, I.S. and Forman, R.T.T. (eds.). Springer Verlag, New York, pp. 191-213.

Taylor, C.M.A. 1990 The nutrition of Sitka spruce on upland restock sites. Forestry Commission Research Information Note No. 164. HMSO, London. 
Waldbauer, J. 1947 Wandlung des Nachhaltbegriffs? Allg Forstzeitschrift 2, 105-107. Walters, C. 1986 Adaptive Management of Renewable Resources. Macmillan, New York.

Will, G.M. 1978 Nutrient deficiencies in Pinus radiata in New Zealand. N. Z. J. For. Sci. 8, 4-14.

Willis, K.G and Garrod, G.D. 1992 Amenity value of forests in Great Britain and its impact on the internal rate of return from forestry. Forestry 65, 331-346.

Wilson, E.O. and Peters, F.M. (eds) 1988 Biodiversity. National Academy of Sciences Press, Washington DC.

Wondolleck, J.M. 1988 Public Lands Conflict and Resolution: Managing National Forest Disputes. Plenum Press, New York.

Zürchner, U. 1965 Die Idee der Nachhaltigkeit unter spezieller Berucksichtigung der Gesichtspunkte der Forsteinrichtung. Mitteilungen der Schweizerische Anstalt für das forstliche Versuchswesen 41(4), 91-218.

Received 8 January 1993 
Downloaded from https://academic.oup.com/forestry/article-abstract/66/4/395/568346 by Lib4RI Empa user

on 06 August 2018 